\title{
39. INERT-GAS CONTENTS OF ALTERED SAMPLES FROM DEEP SEA DRILLING PROJECT HOLES 501, 504B, AND 505B, COSTA RICA RIFT ${ }^{1}$
}

\author{
D. J. Terrell ${ }^{2}$ and J. G. Mitchell, School of Physics, The University, \\ Newcastle upon Tyne, NE1 7RU, United Kingdom
}

\begin{abstract}
"Conventional" $\mathrm{K}-\mathrm{Ar}$ ages have been determined and inert-gas abundances have been measured on representative samples of altered rocks from Deep Sea Drilling Project Holes 501, 504B, and 505B in an attempt to correlate their degree of alteration with inert-gas and $\mathrm{K}-\mathrm{Ar}$ data.

Samples taken from the first 60 meters below the sediment/basalt interface give significantly higher ages than would be expected from the magnetic stratigraphy, though at greater depths the calculated ages are in broad agreement with the expected age.

The inert gas ratios ${ }^{20} \mathrm{Ne} /{ }^{36} \mathrm{Ar},{ }^{36} \mathrm{Ar} /{ }^{84} \mathrm{Kr}$, and ${ }^{84} \mathrm{Kr} /{ }^{130} \mathrm{Xe}$ also show a marked discontinuity at the 60 -meter depth, and all these effects are interpreted as being a consequence of low-temperature alteration produced by burial metamorphism and by interaction with sea water (halmyrolysis).
\end{abstract}

\section{INTRODUCTION}

Mid-ocean-ridge basalts (MORB), by virtue of their youth and low potassium content, should be particularly susceptible to the effects of anomalous initial argonisotope ratios.

The present study was carried out to evaluate the effects of alteration on MORB samples inasmuch as it leads to loss or gain of argon and potassium. The samples are from Holes 501, 504B, and 505B, Costa Rica Rift, drilled during Legs 68, 69, and 70 (Fig. 1). The other inert gases $(\mathrm{Ne}, \mathrm{Kr}$, and $\mathrm{Xe}$ ) have also been investigated, to determine whether any systematic variation exists which could be correlated with degree of alteration. In this way, we hoped to establish the composition of the inert gases in the "primitive," unaltered material from which these samples have evolved.

\section{EXPERIMENTAL METHOD}

Samples were crushed, sieved to 5- to 16-mesh, washed in distilled water, and dried to $110^{\circ} \mathrm{C}$. Duplicate analysis of potassium was carried out with an EEL 450 flame photometer. Approximately $2 \mathrm{~g}$ of sample were fused in ultra-high vacuum, using a RF induction heater to achieve total fusion $\left(\sim 1400^{\circ} \mathrm{C}\right)$. After passing the gas through zeolite and hot $\left(600^{\circ} \mathrm{C}\right) \mathrm{Cu}-\mathrm{CuO}$, the mixture was cleaned twice using a titanium getter. ${ }^{38} \mathrm{Ar}$ spike was added after the first gettering.

The gas was analyzed with a modified AEI MS10. The detection limits for $\mathrm{Ne}, \mathrm{Ar}, \mathrm{Kr}$, and $\mathrm{Xe}$ are $1.5 \times 10^{-10}, 6 \times 10^{-11}, 6 \times 10^{-11}$, and $4 \times 10^{-11} \mathrm{~cm}^{3}$ at STP, respectively. The lower sensitivity for Ne stems from the fact that Ne cannot be trapped with the activated charcoal at liquid-nitrogen temperature. The resolution is approximately 180 at mass 130 and is just adequate to resolve ${ }^{130} \mathrm{Xe}$ from the ${ }^{129} \mathrm{Xe}$ and ${ }^{131}$ Xe peaks.

\section{SAMPLE DESCRIPTION}

The analyzed samples comprised aphyric to holocrystalline basalts, chosen to be representative of the full

\footnotetext{
${ }^{1}$ Cann, J. R., Langseth, M. G., Honnorez, J., Von Herzen, R. P., White, S. M., et al., Init. Repts. DSDP, 69: Washington (U.S. Govt. Printing Office).

2 On leave of absence from Instituto de Geofísica, Universidad Nacional Autónoma de México, México 20, D.F., México.
}

range, "slightly" altered to "strongly" altered. Most contain olivine and plagioclase phenocrysts ranging in abundance from $<1 \%$ to $\sim 10 \%$ and in size from 0.5 to $5 \mathrm{~mm}$. The olivine in samples from Holes 501 and 504B is completely altered.

Holes 501 and 504B have a magnetic-anomaly age of 6.2 m.y., and Hole 505B 3.9 m.y. (early Pliocene).

It is significant in the discussion that follows that there is no evidence of high-temperature alteration in any of the analyzed samples. Temperatures measured in the basement of Holes 501 and 504B ranged between about 50 and $100^{\circ} \mathrm{C}$ (Becker et al., this volume). Isotopic evidence (Mottl, Lawrence, et al., this volume) suggest that at least some of the alteration of these basalts took place at these temperatures. The observed low temperature in Hole 505B (Site 505 chapter, this volume) suggests that the small amount of alteration there took place at no more than $10^{\circ} \mathrm{C}$.

Vesicles are not abundant $(<1 \%)$. In some samples, they are filled with smectite, and all secondary minerals are "low-temperature," probably formed by halmyrolysis. There is no systematic correlation between alteration and depth, but as found by Rhodes et al. (1979) there is a difference in alteration between aphyric and phyric basalts.

The sample from Piece 186 from Hole 505B is markedly the least altered of the analyzed samples and was originally considered to be representative of "fresh" basalt. The sample from Piece 564 of Hole 504B is slightly altered and comes from the center of an aphyric massive flow.

\section{RESULTS AND DISCUSSION}

A summary of our results is presented in Table 1. As yet, no precise classification of degree of alteration is available from the shipboard microscopic description; consequently, it is not yet possible to establish any firm correlation between anomalous age and alteration state. A plot of age against depth (below sediment/basalt in- 


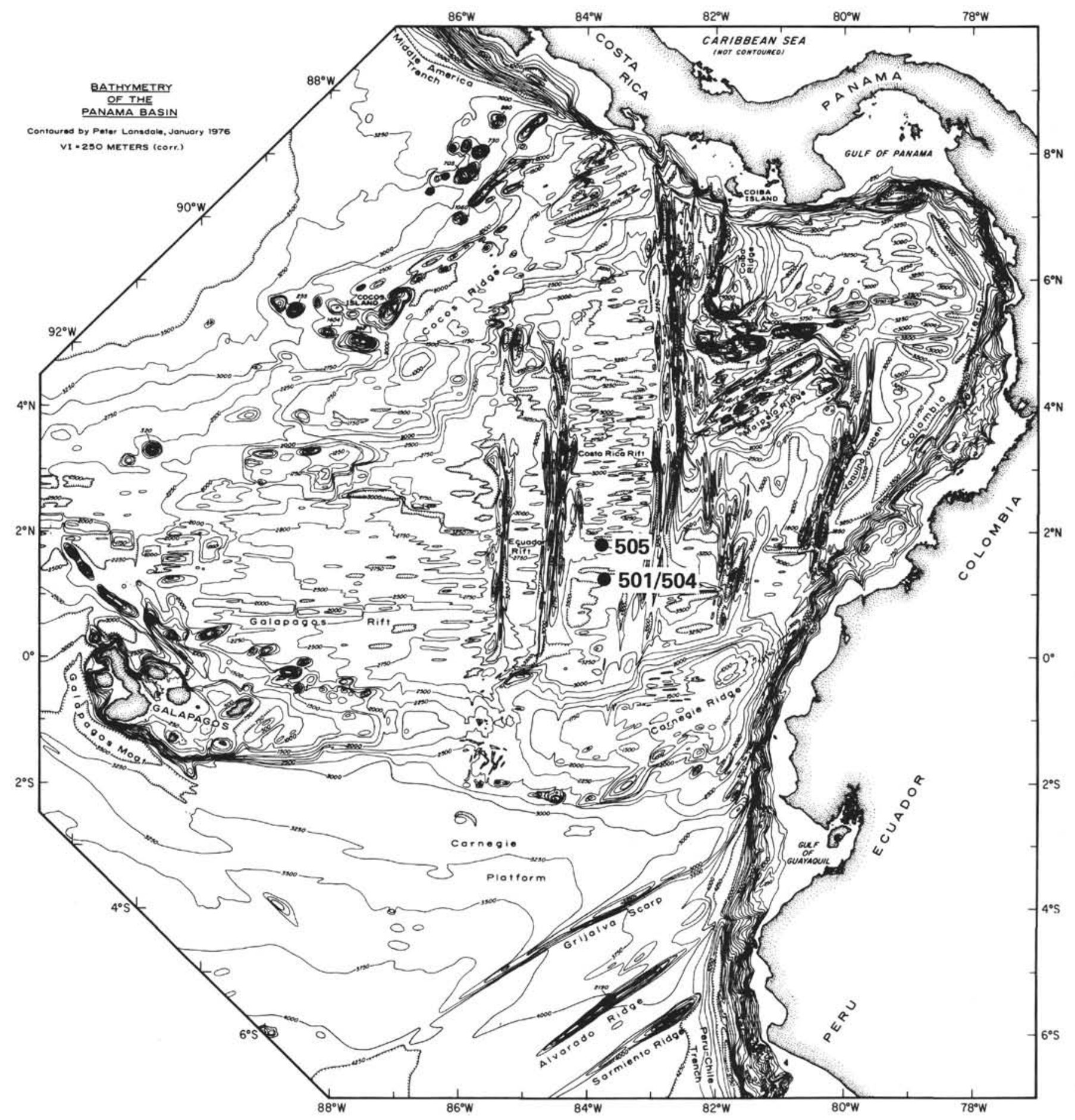

Figure 1. Location of Holes 501, 504B, and 505B near the Costa Rica Rift.

terface; Fig. 2) shows that from all three holes anomalously "old" $\mathrm{K}$-Ar ages occur in samples taken from above the 60-meter level (measured from the sediment/ basalt interface). It is also evident that these "high age" samples have low $(<0.1 \%) \mathrm{K}_{2} \mathrm{O}$ (Fig. 3).

It has been recognized for some time (Dalrymple and Moore, 1968; Seideman, 1978) that "conventional"' KAr dating cannot be applied successfully to MORB samples, because sea-water alteration can lead to exchange of both potassium and argon, and also because there is uncertainty regarding the initial $\mathrm{Ar}$ composition in such samples.

Low-temperature sea-water alteration (halmyrolysis) should increase the potassium content (Hart, 1969; Hart, 1970; Terrell et al., 1979) of MORB, and as a consequence the $\mathrm{K}-\mathrm{Ar}$ age would be lower than the true age of emplacement; however, as was mentioned earlier, the samples which yield "anomalous" ages are those with low potassium, and none is anomalously young, thus suggesting that some peculiarity in the inert-gas isotopic 
Table 1. $\mathrm{K}-\mathrm{Ar}$ age and inert-gas-isotope data.

\begin{tabular}{|c|c|c|c|c|c|c|c|c|c|c|}
\hline Leg & $\begin{array}{c}\text { Sample } \\
\text { (interval in } \mathrm{cm} \text { ) }\end{array}$ & $\begin{array}{c}\text { Piece } \\
\text { Number }\end{array}$ & $\begin{array}{l}\text { Deptha }^{a} \\
\text { (m) }\end{array}$ & $\begin{array}{l}\mathrm{K}_{2} \mathrm{O} \\
(\%)\end{array}$ & $\begin{array}{c}{ }^{40} \mathrm{Ar}(\mathrm{rad}) \\
\left(10^{-8} \mathrm{ccSTP} / \mathrm{g}\right)\end{array}$ & $\begin{array}{c}\text { K-Ar Age }{ }^{b} \\
(m . y .) \\
\left( \pm \text { error }^{c}\right)\end{array}$ & $\begin{array}{c}{ }^{36} \mathrm{Ar} \text { (total) } \\
\left(10^{-9} \mathrm{ccSTP} / \mathrm{g}\right)\end{array}$ & $20 \mathrm{Ne} / 36 \mathrm{Ar}$ & $\begin{array}{c}{ }^{84} \mathrm{Kr} /{ }^{36} \mathrm{Ar} \\
\left(\times 10^{-2}\right)\end{array}$ & $\begin{array}{c}{ }^{132} \mathrm{Xe} /{ }^{36} \mathrm{Ar} \\
\left(\times 10^{-3}\right)\end{array}$ \\
\hline \multirow[t]{4}{*}{68} & $501-13-1,86-90$ & 127 & 16.98 & 0.03 & 5.7 & $65 \pm 64$ & 13 & 3.4 & 2.7 & 1.9 \\
\hline & $17-1,107-111$ & 295 & 42.19 & 0.03 & 7.8 & $69 \pm 42$ & 13 & 3.0 & 3.3 & 2.0 \\
\hline & $20-1,100-115$ & 420 & 65.18 & 0.20 & 2.2 & $4 \pm 3$ & 4.1 & 9.7 & 1.1 & - \\
\hline & $20-3,25-30$ & 446 & 67.38 & 0.24 & 6.9 & $9 \pm 7$ & 4.3 & 18.3 & 1.3 & - \\
\hline \multirow[t]{13}{*}{69} & $504 \mathrm{~B}-4-4,124-127$ & 341 & 11.26 & 0.08 & 14 & $58 \pm 24$ & 8.8 & 4.2 & 2.7 & 7.4 \\
\hline & $6-2,57-60$ & 418 & 26.09 & 0.04 & 4.2 & $36 \pm 30$ & 7.5 & 7.1 & 2.8 & 3.5 \\
\hline & $8-5,56-62$ & 564 & 48.59 & 0.03 & 15 & $140 \pm 40$ & 9.9 & 7.1 & 3.9 & 4.3 \\
\hline & $9-1,65-71$ & 574 & 51.68 & 0.10 & 12 & $35 \pm 17$ & 8.9 & 1.8 & 2.5 & 1.5 \\
\hline & $11-1,74-80$ & 669 & 69.77 & 0.23 & 2.3 & $3 \pm 3$ & 7.2 & 3.3 & 1.5 & - \\
\hline & $13-3,33-38$ & 788 & 90.36 & 0.23 & 6.3 & $8 \pm 3$ & 5.5 & 9.2 & 1.7 & 2.6 \\
\hline & $13-3,132-139$ & 800 & 91.36 & 0.29 & 9.3 & $10 \pm 5$ & 4.9 & 13.2 & 1.6 & - \\
\hline & $15-2,136-142$ & 904 & 103.39 & 0.19 & 3.0 & $5 \pm 4$ & 5.9 & 12.2 & 1.6 & - \\
\hline & $16-5,27-36$ & 1021 & 115.82 & 0.18 & 6.1 & $10 \pm 4$ & 5.3 & 10.0 & 1.9 & - \\
\hline & $19-1,5-8$ & 1113 & 128.97 & 0.32 & 12 & $12 \pm 7$ & 9.9 & 2.2 & 2.1 & - \\
\hline & $24-2,100-105$ & 1367 & 176.03 & 0.21 & 5.5 & $8 \pm 3$ & 4.8 & 8.2 & 2.0 & 3.6 \\
\hline & $25-2,69-76$ & 1430 & 184.73 & 0.35 & 6.1 & $5 \pm 2$ & 5.2 & 8.3 & 3.2 & 4.5 \\
\hline & $29-1,54-58$ & 1565 & 210.06 & 0.43 & 6.2 & $4 \pm 1.5$ & 4.9 & 8.4 & 1.2 & 1.8 \\
\hline 69 & $505 \mathrm{~B}-3-2,62-65$ & 186 & 16.64 & 0.10 & 20 & $61 \pm 20$ & 13 & 2.6 & 3.2 & 3.0 \\
\hline
\end{tabular}

a Sub-basement depth measured from sediment/basalt interface.

b Age calculated using $\lambda_{\mathrm{e}}=0.581 \times 10^{-10} \mathrm{yr}^{-1}, \lambda_{\beta}=4.962 \times 10^{-10} \mathrm{yr}^{-1}$ and $40 \mathrm{~K} / \mathrm{K}=1.167 \times 10^{-4}$.

c Atmospheric contamination was between 87 and $99.4 \%$.

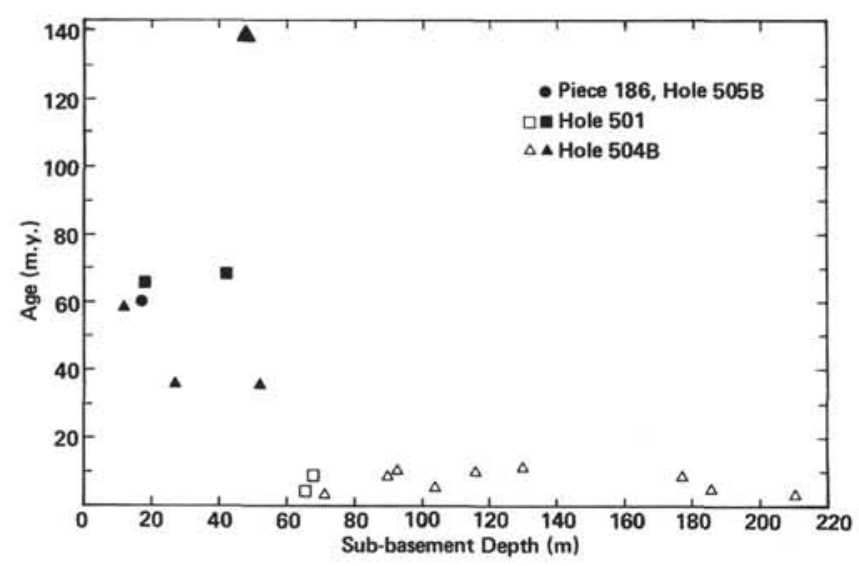

Figure 2. Variation of $\mathrm{K}-\mathrm{Ar}$ age with depth. Depth measured from sediment/basalt interface. We have distinguished the samples with "anomalous" high age with a solid black sign, and Piece 564 with a larger triangle.

composition is the dominant cause of the anomalous ages.

An examination of the $\mathrm{Ne}, \mathrm{Ar}, \mathrm{Kr}$, and $\mathrm{Xe}$ isotopes supports this conclusion, as demonstrated below.

We have plotted $\mathrm{Ne}, \mathrm{Ar}, \mathrm{Kr}$, and $\mathrm{Xe}$ isotopic ratios using the procedure suggested by Saito (1978), namely ${ }^{84} \mathrm{Kr} /{ }^{130} \mathrm{Xe}$ versus ${ }^{20} \mathrm{Ne} /{ }^{36} \mathrm{Ar}$, and ${ }^{36} \mathrm{Ar} /{ }^{84} \mathrm{Kr}$ versus ${ }^{20} \mathrm{Ne} /$ ${ }^{36} \mathrm{Ar}$ (Figs. 4 and 5).

From these figures, we can see that all our samples lie in the field established by Saito (1978) for "ridge basalts"' (mainly MORB glassy rims), which correspond to type 2 samples of Ozima and Alexander (1976), for which they claim that there is clear isotopic evidence that these samples contain non-atmospheric rare gases. The samples with "anomalously" high age cluster in the lower left sector of the field in Figure 4, and fall in the left of the field in Figure 5. In both figures, the "anom-

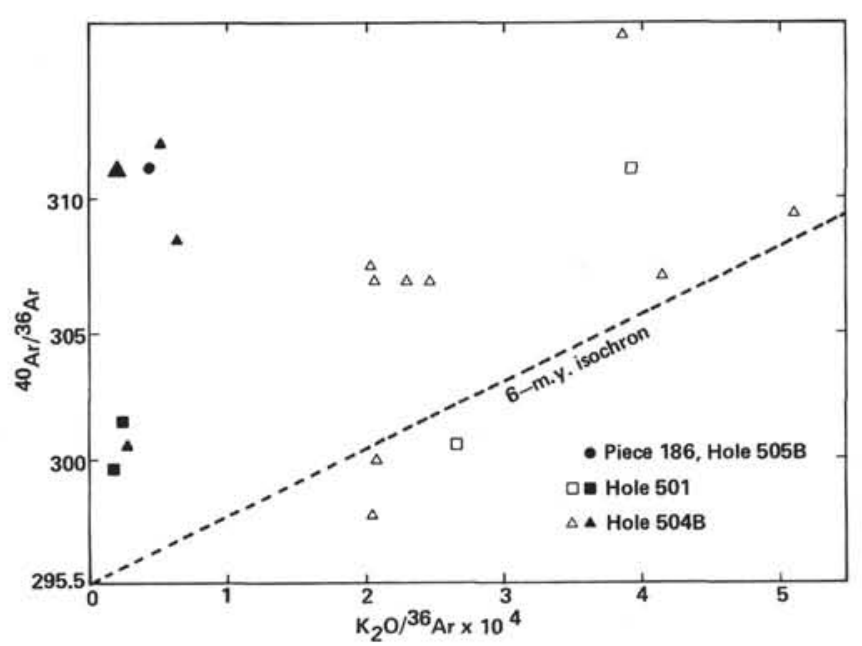

Figure 3. K-Ar "isochron" diagram.

alous age" data points trend along a direction which has as one end the field named "surface water" (in which Saito, 1978, included data for holocrystalline MORB). The samples whose $\mathrm{K}-\mathrm{Ar}$ dates are in reasonable agreement with the magnetic-anomaly evidence seem to lie remote from the "surface water" region.

Recrystallization of igneous rocks due to low-grade burial metamorphism can occur while still preserving the original igneous texture (Miyashiro et al., 1971). This process may lead to out-gassing of any excess radiogenic argon incorporated during the original crystallization (Cann, 1971). Such a process (as well as the gain in potassium) is envisaged as occurring over periods of tens of thousands of years. Thus, the $\mathrm{K}-\mathrm{Ar}$ clock would be "set" at a time close to the age of emplacement, and in the absence of "excess" argon the correction for "atmospheric" argon by the conventional method is still val- 


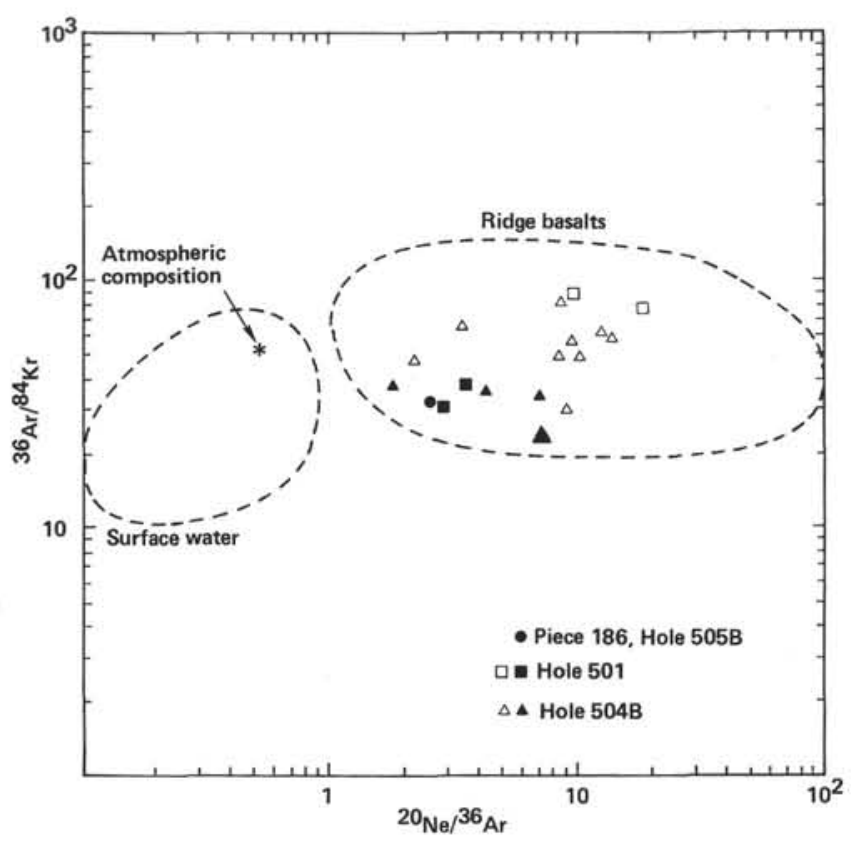

Figure 4. $\mathrm{Kr}, \mathrm{Ar}$, Ne isotopic ratios.

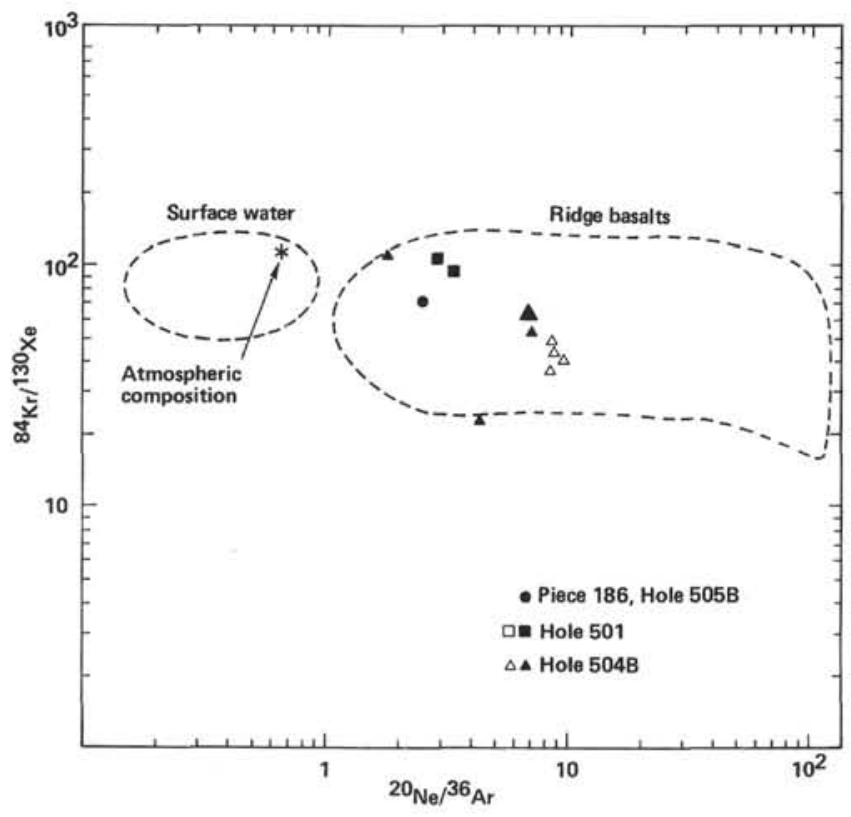

Figure 5. $\mathrm{Xe}, \mathrm{Kr}, \mathrm{Ar}$, $\mathrm{Ne}$ isotopic ratios.

id. It appears therefore that those samples with anomalous high age may represent less-disturbed inert-gas abundances, whereas those samples with age in broad agreement with the magnetic anomaly may have lost any "initial" inert gases through the mechanism described.

If we examine the behavior of the whole range of inert gases under such metamorphic conditions, we might expect at least two processes to occur.

1) If the recrystallization were to occur in the presence of water containing a low partial pressure of inert gases (a "juvenile" water), then, because the solubility of inert gases in water increases with increasing atomic number, a preferential loss of heavy gases would result.

2) During recrystallization, we might expect the lighter inert gases to be assimilated more readily into mineral structures at the expense of the heavier (and largeratomic-size) gases. Both of the described effects would lead to a trend to the right and upward in Figures 4 and 5 , following a pattern of increasing alteration away from the "surface-water" region. A "hypothetical" unaltered composition might be represented by Sample 504B-8-5, $56-62 \mathrm{~cm}$, Piece 564, which exhibits an extraordinary high age and high inert-gas abundance.

The absolute concentration of inert gases in sea water exceeds that observed in the unaltered rocks, and, because the "reservoir" of inert gases in sea water is large, any exchange of inert gases between igneous rocks and sea water will tend to move the data points in Figures 4 and 5 toward the "surface-water" field. On this basis the Piece 186 from Hole 505B-far from being "fresh" as inferred from petrographic examination-shows considerably more isotopic exchange with sea water than Piece 564, an observation supported by the slightly higher potassium concentration in Piece 186 relative to Piece 564.

For those samples which have not appreciably lost inert gases (giving anomalous high ages, particularly Pieces 564 and 186) we can extrapolate in Figure 3 using a 6-m.y. isochron to find the intercept on the ordinate axis representing the "non-radiogenic" ${ }^{40 / 36} \mathrm{Ar}$ ratio which has resulted from a combination of factors involving initial argon plus atmospheric contamination and some diffusional loss (Shafigullah and Damon, 1974).

If the atmospheric-contamination and diffusionalloss effects are negligible, we can infer that these samples had an initial ${ }^{40} \mathrm{Ar} /{ }^{36} \mathrm{Ar}$ ratio of approximately 310 , slightly higher than the present-day atmospheric value.

If this value of 310 for ${ }^{40} \mathrm{Ar} /{ }^{36} \mathrm{Ar}$ resembles the "original" composition of the source magma in the mantle, then it conflicts with the much higher values for the mantle of 2000 or 5000 suggested by Ozima and Kudo (1972) and Hamano and Ozima (1978), respectively.

\section{CONCLUSIONS}

The variations of $\mathrm{K}-\mathrm{Ar}$ ages of MORB, together with the range of inert-gas isotopic compositions are consistent with the operation of two low-temperature alteration processes-halmyrolysis and burial metamorphism. We hope that inert-gas isotopic data will support the oxygen- and strontium-isotope data in distinguishing the two processes.

It is possible (using initial ${ }^{40} \mathrm{Ar} /{ }^{36} \mathrm{Ar}$ ratios in the samples with anomalous high age) to predict inert-gas composition of the source magma from which these samples originate; in the case of this set of samples, we suggest an initial rare-gas composition similar to that given by Piece 564.

\section{ACKNOWLEDGMENTS}

We would like to thank Jack Miller, Surendra Pal Verma, David Rex, and Chris Roddick for their thorough and constructive criticisms of the manuscript. 
We gratefully acknowledge Joe Cann for his stimulating discussion concerning the alteration of sea-floor samples, and for introducing us to the DSDP.

\section{REFERENCES}

Cann, J. R., 1971. Petrology of basement rocks from Palmer Ridge, NE Atlantic. Phil. Trans. Royal Soc. Lond., A., 268:605-617.

Dalrymple, G. B., and Moore, J. G., 1968. Argon 40: excess in submarine pillow basalts from Kilawai Volcano, Hawaii. Science, 161: 1132-1135.

Hamano, Y., and Ozima, M., 1978. Earth-atmosphere evolution model based on Ar isotopic data. In Alexander, E. C., Jr., and Ozima, M. (Eds.), Terrestrial Rare-Gases: Tokyo (Cent. Acad. Publ. Japan), pp. 155-171.

Hart, R., 1970. Chemical exchange between sea water and deep ocean basalts. Earth Planet. Sci. LEtt., 9:269-279.

Hart, S. R., 1969. K, Rb, Cs contents and K/Rb, K/Cs ratios of fresh and altered submarine basalts. Earth Planet. Sci. Lett., 6:295-303.

Miyashiro, A., Shido, F., and Ewing, M., 1971. Metamorphism in the Mid-Atlantic Ridge near $24^{\circ}$ and $30^{\circ} \mathrm{N}$. Phil. Trans. Royal Soc. Lond., A, 268:589-603.
Ozima, M., and Alexander, E. C., Jr., 1976. Rare-gas fractionation patterns in terrestrial samples and earth-atmosphere evolution model. Rev. Geophys. Space Phys., 14:385-390.

Ozima, M., and Kudo, K., 1972. Excess argon in submarine basalts and an Earth-atmosphere evolution model. Nature, 239:23-24.

Rhodes, J. M., Dungan, M. A., Blanchard, D. P., and Long, P. E., 1979. Magma mixing at mid-ocean ridges: evidence from basalts near $22^{\circ} \mathrm{N}$ on the Mid-Atlantic Ridge. In Toksöz, M. N., Uyeda, S., and Francheteau, J. (Eds.), Oceanic Ridges and Arcs: Geodynamic Processes. Devel. Geotectonics, 14:251-277.

Saito, K., 1978. Classification of terrestrial rare gases. In Alexander, E. C., Jr., and Ozima, M. (Eds.), Terrestrial Rare Gases: Tokyo (Cent. Acad. Publ. Japan), pp. 145-153.

Seideman, D., 1978. ${ }^{40} \mathrm{Ar} /{ }^{39} \mathrm{Ar}$ studies of deep sea igneous rocks. Geochim. Cosmochim. Acta, 42:1721-1734.

Shafiqullah, M., and Damon, P. E., 1974. Evaluation of K-Ar isochron methods. Geochim. Cosmochim. Acta, 38:1341-1358.

Terrell, D. J., Pal, S., Lopez, M. M., and Perez, R. J., 1979. Rareearth elements in basalt samples, Gulf of California. Chem. Geol., $26: 267-275$. 